Forcada N., Gangolells M., Casals M., Macarulla M. Factors Affecting Rework Costs in Construction. Journal of Construction Engineering and Management, 2017, 20(4): 445-465. <doi: 10.1061/(ASCE)CO.1943-7862.0001324>

Final version available at: <http://ascelibrary.org/doi/abs/10.1061/\%28ASCE\%29CO.19437862.0001324>.

\title{
Factors Affecting Rework Costs in Construction
}

\author{
Nuria Forcada $^{1}$, Marta Gangolells ${ }^{2}$, Miquel Casals ${ }^{3}$, Marcel Macarulla $^{4}$ \\ 1 Associate Professor. Department of Project and Construction Engineering (DPCE), Group of \\ Construction Research and Innovation (GRIC), Universitat Politècnica de Catalunya (UPC), C/ Colom, \\ 11, Ed. TR5, 08222 Terrassa, Barcelona, Spain. E-mail: nuria.forcada@upc.edu (corresponding author).
}

${ }^{2}$ Lecturer. DPCE, GRIC, UPC.

${ }^{3}$ Associate Professor. DPCE, GRIC, UPC.

${ }^{4}$ Assistant Lecturer. DPCE, GRIC, UPC.

\begin{abstract}
Rework adversely impacts the performance of building projects. In this study, data were analyzed from 788 construction incidents in 40 Spanish building projects to determine the influence of project and managerial characteristics on rework costs. Finally, regression analysis was used to understand the relationship between the contributing factors, and to determine a model for rework prediction.Interestingly, the rework prediction model showed that only the original contract value (OCV) and the project location in relation to the company's headquarters contribute to the regression model. The Project type, the Type of organization, the Type of contract and the original contract duration (OCD) which represents the magnitude and complexity of a project, were represented by the OCV. This model for rework prediction based on original project conditions enables strategies to be put in place prior to the start of construction, to minimize uncertainties and reduce the impact on project cost and schedule, and thus improve productivity.
\end{abstract}

Author keywords:

rework costs, project characteristics, construction, regression model. 


\section{INTRODUCTION}

Rework is an endemic problem in building projects, and can have an adverse impact on the performance (CII, 2001; Hwang et al., 2009; Love et al., 2009; Love et al. 2010, Wanberg et al., 2013; Love et al. 2015) of construction and engineering projects. On average, rework contributes to $52 \%$ of the total cost growth that is incurred, and can increase the schedule overrun by $22 \%$ (Love, 2002). Rework costs have been found to range from $5 \%$ to $20 \%$ of the contract value in construction and engineering projects, and changes in the scope of the design account for as much as 50\% of the rework that occurs (Barber et al., 2000; Love and Edwards, 2004). However, the varying interpretations and lack of uniformity in rework data collation (Love and Smith, 2003; Palaneeswaran et al., 2008) make it difficult to compare these studies and define general preventive measures. Despite the considerable amount of research that has been undertaken to date (Love et al., 2010), empirical research to determine the costs of rework using predictors may provide uncertain results (e.g., Love and Edwards, 2004), essentially because it is only based on questionnaires. Notably, there is a little evidence of a reduction in rework in projects (e.g., Aiyetan, 2013; Hwang et al., 2014; Kakitahi et al., 2014; Taggart et al., 2014; Jingmond and Ågren, 2015). The primary objective of the research reported in this paper was to determine the influence of project and managerial aspects on rework costs, using data from 788 incidents that occurred at Spanish construction sites. While the research was conducted in Spain, it is expected that the outcome could be widely applicable in other locations.

\section{REWORK IN CONSTRUCTION}

In the building industry, words like "error", "fault", "failure", "defect", "quality deviation", "non-conformance", "quality failure", "snag" and "rework" are used interchangeably to describe imperfections in buildings (Georgiou et al., 1999; Josephson et al., 2002; Love, 2002; Sommerville and McCosh, 2006; Mills et al., 2009). These words are emotive and mean different things to different people. However, they always suggest that the client is not satisfied with the solution (Ilozor et al., 2004). A lack of differentiation between these terms can lead to inaccurate, incomplete measurements and cost determinations, and possibly inappropriate strategies for reducing their occurrence (Mills et al., 2009).

Although Davis et al. (1989) consider that no practical difference exists between nonconformance and defects, ISO 9000:2005 defines non-conformance as "the failure to fulfil a requirement", and defect as "the non-fulfilment of a requirement related to an intended or specified use". In fact, non-conformance occurs when the finished state of a project and/or its components deviate from established requirements, and decisions must be made regarding acceptance and/or rectification (Battikha, 2008). However, Watt (1999) considers that "defect is the term used to define a failing or shortcoming in the function, performance, statutory or user requirements of a building, and might manifest itself within the structure, fabric, services or other facilities of the affected building". The occurrence and subsequent rectification of a defect can be called rework, which is defined as "the unnecessary effort of redoing an activity or process that was incorrectly implemented the first time" (Love, 2002; Love and Edwards, 2004). Ashford 
(1992) includes the term repair and defines it as "the process of restoring a nonconforming characteristic to an acceptable condition even though the item may not still conform to the original requirement". Consequently, rework includes items such as design errors/changes, which do not necessarily result in defects (Mills et al., 2009).

\section{REWORK COSTS}

According to Love et al. (2010), rework costs are a major contributor to cost growth and schedule overrun in building construction projects. However, data on rework is usually difficult to obtain (Yung and Yip, 2010) and varying interpretations and definitions of rework have led to a lack of uniformity in rework data collation and quantification (Love and Smith, 2003). As an example, Josephson and Hammarlund (1999) reported that the cost of rework on residential, industrial, and commercial building projects ranged from $2 \%$ to $6 \%$ of the contract values, while Fayek et al. (2003) established that this figure ranged from $2 \%$ to $12 \%$. Similarly, Love and Li (2000) found direct rework costs to be $3.15 \%$ of the contract value in residential projects, and $2.4 \%$ in industrial buildings. Findings by Josephson et al. (2002) revealed that the rework costs were $4.4 \%$ of the construction value, and Love (2002) found that direct and indirect rework costs accounted for $6.4 \%$ and $5.6 \%$, respectively, of the original contract. Correspondingly, Oyewobi et al. (2011) found that rework accounted for 5.06\% of the completion cost of new buildings, and $3.23 \%$ of the completion cost of refurbished buildings. Burati et al. (1992) indicated that quality deviations accounted for an average of $12.4 \%$ of the contract value in nine major engineering projects, and Mills et al. (2009) found defects that represented $4 \%$ of the contract value of the new dwelling or renovation.

In civil infrastructure projects, total rework costs were found to be $10.29 \%$ (Love et al., 2010) and $16.5 \%$ of the contract value (Forcada et al., 2014a), while non-conformance costs (excluding material wastage and head office overheads) accounted for only $5 \%$ of the contract value (Abdul-Rahman, 1993). Such differences were further compounded by the methods used to quantify rework costs, which also influenced determinations of the causal nature of the rework costs (Fayek et al., 2003; Love and Edwards, 2004; Love and Sing, 2013).

Love (2002) found that the mean schedule overrun was 20.7\%. Moreover, Love (2002) found that cost growth and schedule overruns were significantly correlated with direct rework costs, which suggests that rework can adversely influence project performance (Palaneeswaran et al., 2006).

\section{FACTORS CONTRIBUTING TO REWORK}

Project characteristics have been identified as predictors of performance in construction works (Walker, 1994). These characteristics include construction costs, project duration, gross floor area (GFA), the number of stories, the building type and the procurement method (Love and Edwards, 2004). 
Previous research (Walker, 1994; Love, 2002; Love and Edwards, 2004) found that there were no significant differences between procurement methods and the cost growth and schedule overrun experienced in building and civil infrastructure projects. Love (2002) also revealed that GFA and the number of stores in building construction projects were not significantly related to rework costs.

In relation to the type of project, Bresnen et al. (1989) stated that facility type is an attribute rather than a causal factor, and thus does not influence project performance. However, the National Economic Development Office (NEDO, 1987) and Naoum and Mustapha (1994) indicated that project type is linked to the concept of complexity, and thus influences project performance and rework costs (Hwang et al., 2009). In fact, some types of projects, such as refurbishment and renovation, lead to higher rework costs than building projects, because of the higher degree of uncertainty and complexity associated with such works (Love and Wyatt, 1997). Similarly, Jaafari et al. (1994) found that rework costs have different implications in commercial buildings, road construction, and industrial buildings.

Regarding the project's original contract value, Jaafari et al. (1994) suggested that larger projects incur lower quality failure costs. However, Hwang et al. (2009) revealed that rework contributed most to projects with a cost range between $\$ 50$ million and $\$ 100$ million, but not to projects with costs above $\$ 100$ million.

Previous studies (e.g. Ye et al., 2014; Palaneeswaran et al., 2008; Love et al., 1999, 2002, 2010; Love and Edwards, 2004; Josephson et al., 2002) also identified managerial aspects as key factors contributing to rework. Owner changes and design error/omission are considered to be root causes of rework, and have a relatively greater cost impact than other reasons (Hwang et al., 2009, 2014; Love and Edwards, 2013). Correspondingly, design inconsistencies and reliance on the IT application output when projects are subjected to tight design schedules are also considered major factors of rework (Love et al., 2009). Finally, when quality frameworks are in place (Kakitahi et al., 2014), other managerial factors are considered to improve project governance and reduce rework. Similar findings were reported in Burati et al. (1992), Abdul-Rahman (1995), and Love et al. (1999).

\section{METHOD}

The aim of the research method was to determine the factors that contribute to rework costs in construction projects. In the selection of data, an effort was made to maximize accuracy and minimize subjectivity. Forster (1992) and Sommer and Sommer (1991) acknowledge the use of archival documentation as a valid research approach. The data used for the purposes of this research were technical datasheets and non-conformance reports provided by one of the largest Spanish contractors. This company uses a structured method to register non-conformances, in accordance with ISO 9001:2008 certification. Therefore, it best met the aims of the research. 
The documents supplied by the contractor were generally accurate, and the inspectors were trained to be conversant with, and follow, set inspection guidelines that ensure objectivity, while reducing or eliminating subjectivity.

Although the literature review identified different factors as contributors to rework costs, the vast majority were related to project type, procurement method, construction costs and project duration, which were included in this study. Factors which did not apply to all types of projects, such as the GFA or number of stories, were not included in the study (civil infrastructure works, for example, cannot be defined using this parameter). Other managerial aspects that were impossible to quantify were also excluded (e.g. design inconsistencies and tight design schedules). Furthermore, although no previous research analyzed location in relation to headquarters, the impact of this factor on organizational aspects and the difficulties of quality control due to distance suggest that it could also affect rework costs. Finally, as all the analyzed projects had quality frameworks in place, this factor was excluded from the study.

Out of all of the potential contributors to rework costs, only available and quantifiable factors were used in the study. These included general aspects (project type and project location) and managerial aspects (type of contract, original contract value [OCV], original construction duration [OCD], contract value on practical completion [CVP] and actual construction duration $[\mathrm{ACD}])$. Generally, this information was obtained from the description of the projects included in the technical datasheets, while rework costs were obtained from non-conformance reports. However, data that are only drawn from archival documentation must be checked, interpreted and triangulated with other data sources (Forster, 1994). In fact, Forster (1994) suggests that such data are contextspecific, and must be contextualized with other forms of research. To overcome these difficulties, unstructured interviews with project managers were undertaken to check internal consistency, reliability and validity, gain a better understanding of how the projects' technical datasheets were compiled, and assist with the analysis of information derived from non-conformance reports. The documentation obtained from the databases and the results of project managers' interviews were used to:

- Classify each project by project type, project location in relation to the headquarters, type of contract, and type of organization.

- Determine the OCV, OCD, CVP and ACD.

- Calculate the cost growth and schedule overrun.

- Determine the cost of rework of each project.

Project characteristics included project type (building / civil infrastructure), project location in relation to company headquarters (local, regional, national or international), OCV and OCD. Managerial aspects included type of contract (public / private) and type of organization (joint venture / one company). The completion characteristics were CVP, ACD and rework costs.

Finally, data from 788 incidents in 40 construction projects were collected. The data were analyzed using the Statistical Package for the Social Sciences (SPSS) for Windows (version 17.00). Projects that had missing data were eliminated from the analysis. 
SPSS was used to test the associations between OCV, OCD and rework costs by computing Pearson's correlation coefficient. This identified variables that had significant correlations at the 95 and $99 \%$ confidence intervals. SPSS was also used to identify whether there were any differences between samples (i.e. rework costs in building and civil engineering projects, rework costs in public and private projects) by means of a t-test or ANOVA for normal distributions and equal variances of the groups. The normality of the sample was tested using the Shapiro-Wilkinson test. For nonnormal distributions, the Mann Whitney non-parametric test was performed. The homogeneity of variance was tested using Levene's test. For groups with different variances, the Welch-Satterthwaite test, which is an adaption of the t-test, was performed. Finally, a stepwise regression model was used to determine the relationship between the contributing factors and create a model for rework prediction.

\section{SAMPLE CHARACTERISTICS}

The sample was classified into project type, type of contract, type of organization, project location in relation to the headquarters, participation, OCV and OCD (Table 1).

All projects were carried out by the same contractor, which had ISO 9001:2008 certification. The OCV of these projects ranged from $€ 118,290$ to $€ 133,077,629$, the OCD ranged from 1 to 39 months, and all projects were completed between 2005 and 2012. All projects had fixed priced contracts, which are the most common type of contract in Spain.

Civil infrastructure projects comprised $72.5 \%$ of the total, and building projects comprised $27.5 \%$. Public projects accounted for $82.5 \%$ of the total, whilst $17.5 \%$ were private projects. A total of $32.5 \%$ of the projects were managed as joint ventures, while $67.5 \%$ involved only one main contractor. In joint venture projects with 2 contractors, their involvement varied from $60 \%-40 \%, 50 \%-50 \%, 70 \%-30 \%, 52.5 \%-47.5 \%$, $63.5 \%-36.5 \%$ and $75 \%-25 \%$. When the project involved 3 contractors, their involvement varied from $40 \%-30 \%-30 \%, 50 \%-30 \%-20 \%$. 


\begin{tabular}{|c|c|c|c|c|c|c|c|}
\hline 异 & 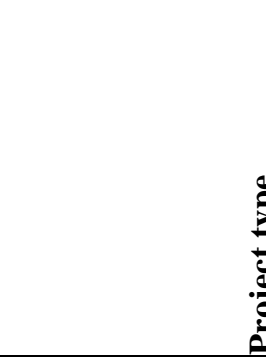 & & 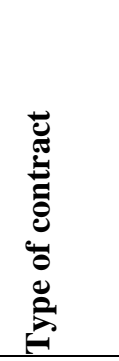 & 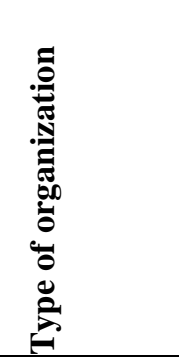 & 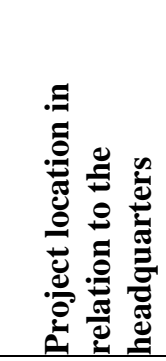 & 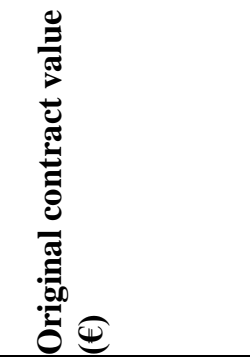 & 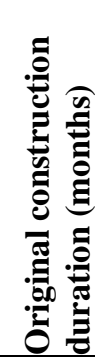 \\
\hline 1 & Road & Civil infr. & Public & Unique & Regional & $4,229,226.75$ & 12 \\
\hline 2 & Institutional buil. & Building & Public & Unique & National & $23,343,661.02$ & 24 \\
\hline 3 & Landscaping & Civil infr. & Private & Unique & Internat. & $32,961,063.27$ & 14 \\
\hline 4 & Landscaping & Civil infr. & Public & Joint Vent. & Regional & $3,698,896.67$ & 30 \\
\hline 5 & Transportation & Civil infr. & Public & Joint Vent. & National & $69,728,084.27$ & 32 \\
\hline 6 & Water and sewer & Civil infr. & Public & Unique & Regional & $6,045,956.58$ & 20 \\
\hline 7 & Institutional buil. & Building & Public & Joint Vent. & National & $41,083,824.75$ & 39 \\
\hline 8 & Transportation & Civil infr. & Public & Joint Vent. & Regional & $32,761,442.48$ & 34 \\
\hline 9 & Road & Civil infr. & Public & Joint Vent. & Regional & $29,791,677.59$ & 20 \\
\hline 10 & Landscaping & Civil infr. & Public & Unique & Local & $1,446,898.29$ & 7 \\
\hline 11 & Landscaping & Civil infr. & Public & Unique & Local & $4,666,862.44$ & 8 \\
\hline 12 & Water and sewer & Civil infr. & Public & Joint Vent. & National & $35,772,164.13$ & 21 \\
\hline 13 & Residential & Building & Public & Unique & Local & $13,113,781.36$ & 22 \\
\hline 14 & Landscaping & Civil infr. & Public & Unique & Local & $3,967,305.03$ & 11 \\
\hline 15 & Water and sewer & Civil infr. & Public & Unique & Regional & $6,591,666.14$ & 35 \\
\hline 16 & Transportation & Civil infr. & Public & Joint Vent. & Regional & $46,697,606.33$ & 36 \\
\hline 17 & Institutional buil. & Building & Public & Joint Vent. & Regional & $133,077,629.75$ & 25 \\
\hline 18 & Road & Civil infr. & Public & Unique & National & $6,817,932.47$ & 9 \\
\hline 19 & Commercial & Building & Private & Joint Vent. & Internat. & $25,464,013.93$ & 18 \\
\hline 20 & Landscaping & Civil infr. & Private & Unique & Local & $3,344,817.00$ & 5 \\
\hline 21 & Road & Civil infr. & Public & Joint Vent. & Regional & $2,772,070.75$ & 14 \\
\hline 22 & Residential & Building & Private & Unique & Local & $5,796,794.58$ & 11 \\
\hline 23 & Transportation & Civil infr. & Public & Unique & National & $10,919,785.80$ & 6 \\
\hline 24 & Transportation & Civil infr. & Public & Unique & National & $1,839,145.29$ & 5 \\
\hline 25 & Institutional buil. & Building & Public & Unique & Local & $2,591,941.41$ & 5 \\
\hline 26 & Transportation & Civil infr. & Public & Unique & National & $2,412,691.21$ & 5 \\
\hline 27 & Transportation & Civil infr. & Public & Unique & Regional & $18,688,241.38$ & 18 \\
\hline 28 & Road & Civil infr. & Private & Joint Vent. & Regional & $1,839,145.29$ & 22 \\
\hline 29 & Transportation & Civil infr. & Public & Unique & National & $118,290.76$ & 2 \\
\hline 30 & Institutional buil. & Building & Public & Unique & Regional & $4,207,556.56$ & 22 \\
\hline 31 & Institutional buil. & Building & Public & Unique & Regional & $2,542,786.33$ & 19 \\
\hline 32 & Water and sewer & Civil infr. & Public & Joint Vent. & Regional & $1,944,280.68$ & 24 \\
\hline 33 & Landscaping & Civil infr. & Public & Unique & Regional & $798,197.92$ & 9 \\
\hline 34 & Transportation & Civil infr. & Public & Unique & National & $1,095,359.63$ & 4 \\
\hline 35 & Water and sewer & Civil infr. & Private & Unique & Internat. & $3,046,214.79$ & 20 \\
\hline 36 & Transportation & Civil infr. & Public & Unique & National & $1,775,974.65$ & 7 \\
\hline 37 & Industrial & Building & Private & Unique & National & $12,415,240.99$ & 11 \\
\hline 38 & Water and sewer & Civil infr. & Public & Unique & National & $3,526,882.64$ & 10 \\
\hline 39 & Transportation & Civil infr. & Public & Unique & Local & $272,237.68$ & 1 \\
\hline 40 & Institutional buil. & Building & Public & Joint Vent. & Regional & $54,203,889.15$ & 23 \\
\hline
\end{tabular}

Table 1. Projects' characteristics 


\section{DATA ANALYSIS}

Although the mean cost growth for the projects was $11 \%$, with a standard deviation of $14.99 \%$, the total costs of rework were found to vary considerably between projects. Rework costs stood at $2.75 \%$ of the OCV, which is similar to figures reported by Fayek et al. (2003), Love and Li (2000), and Josephson et al. (2002), but lower than that reported by Love (2002), who used a questionnaire.

The data collection method and the special features of the Spanish construction sector were decisive factors in the analysis of these data. Spain has a very rigid procurement system compared to other countries. In the awarding procedure, although being based on the best value system, the price still has an excessively high weighing (de la Cruz et al., 2008) and contractors generally do not take part in the design process (Forcada et al., 2014a). Then, the likelihood of changes in project scope increases (Love et al., $2012 \mathrm{~b}$ ) and the final project costs increase from the estimated ones. Furthermore, Spanish construction projects are mainly contracted at a fixed price, so most rework costs are absorbed by contractors, who cannot allocate them to the total cost of the project (de la Cruz et al., 2008). In this context, increases in cost in Spain are basically caused by extensions to the project's scope that are requested by client rather than rework costs.

The mean schedule overrun for the analyzed projects was $15 \%$, which is similar to the figure $(20.7 \%)$ reported by Love (2002). However, there were many differences in schedule overrun among the analyzed projects. One third of the projects did not experience schedule overrun. This implies that the OCD may have contained "buffers", or items of work were deleted, or construction methods were altered, or a combination of all these factors, so that projects could be delivered on time (Love, 2002). In other projects, the schedule overrun was as high as $200 \%$. This high schedule overrun might be derived from legislation factors. Spanish regulations only include structured and formal processes to manage environmental and health and safety risks (de la Cruz et al., 2008). This situation might lead to errors in planning that can cause high schedule growth.

The distribution of rework costs was determined, in order to examine how these costs are influenced by cost and schedule and analyze the other factors that affect them. In parametric tests such as Pearson's (r) correlation, the student's t-test or the calculation of regression models, samples should be normally distributed. Consequently, the Shapiro-Wilkinson test was used to determine the type of distribution of rework costs. The $\mathrm{p}$ value of this test for a normal distribution was less than 0.05 , assuming that rework costs were not normally distributed. When transformed into a logarithmic function (mean $=10.0754$; standard deviation $=1.7949$ ), the $\mathrm{p}$ value of the ShapiroWilkinson test was not less than or equal to 0.05 , assuming that the logarithmic functions of rework costs were normally distributed and parametric tests could be used to analyze correlations and dependences and to calculate the regression model. 


\section{INFLUENCE OF COST AND SCHEDULE ON REWORK COSTS}

Pearson's (r) correlation was computed using the logarithmic transformation of rework costs to test whether there was a significant relationship between the OCV, the OCD and rework costs. A positive Pearson's ( $r$ ) correlation value indicates that when a variable increases, so does the related variable. In contrast, a negative Pearson's (r) correlation value indicates that when a variable increases, the related variable decreases. According to the results, the correlation coefficients for the data revealed that logarithm of rework costs were significantly related to both OCV $(\mathrm{r}=+0.514, \mathrm{n}=40, \mathrm{p}<0.01$, two tails and $\mathrm{r} 2=0.26[26 \%])$ and $\mathrm{OCD}(\mathrm{r}=+0.477, \mathrm{n}=40, \mathrm{p}<0.01$, two tails and $\mathrm{r} 2=0.23$ [23\%]). In fact, OCV and OCD are linked to the concept of complexity, which is the measure of difficulty of executing a process with a number of complicated individual parts brought together in an intricate operational network to form a work flow to be completed within a stipulated production time, cost and quality (Gigado, 1996). The activities to carry out and the technical intricacies or difficulties of executing individual pieces of work can be determined by the OCV and the OCD. Generally, high OCV and OCD imply highly complex projects, and thus higher rework costs (Li and Taylor, 2014; Love and Sing, 2013; Oke and Ugoje, 2013; Hwang et al., 2009). However, short projects that need to be concluded quickly, such as refurbishment and renovation projects, can be more complex (NEDO, 1987; Naoum and Mustapha, 1994). In very big projects, managerial factors such as the implementation of best practices might reduce complexity and thus positively affect the reduction of rework (Hwang et al., 2009). To better understand project complexity and reflect both the planning and the technical perspective of projects (Wood and Gidado, 2008; Bertelsen, 2003) the OCV/OCD ratio was computed and analysed. According to the results, the correlation coefficients for the data revealed that OCV/OCD was significantly related to the logarithm of rework costs $(\mathrm{r}=+0.538, \mathrm{n}=40, \mathrm{p}<0.01$, two tails and $\mathrm{r} 2=0.29$ [29\%]). This result gives deeper insights into the relationship between complexity and rework. However, project complexity is also influenced by the type of project, and is an important criterion in the selection of an appropriate form of project organisation and suitable arrangement of project procurement (Baccarini, 1996). These parameters are analysed in the following sections.

\section{FACTORS CONTRIBUTING TO REWORK COSTS}

The Shapiro-Wilkinson test was used to determine the distribution of rework cost for each project type, type of contract, type of organization and project location in relation to the headquarters. Then, to determine whether rework costs varied between groups, a t-test or ANOVA was performed.

\subsection{PROJECT CHARACTERISTICS}

The significance of the Shapiro-Wilkinson test for a normal distribution was not less than or equal to 0.05 in either sample ( $\mathrm{p}=0.055$ for civil engineering projects, $\mathrm{p}=0.190$ for building projects). Therefore, one can assume that the logarithm of rework costs in both groups had a normal distribution. A t-test was performed to determine whether the logarithm of rework costs varied between building and civil infrastructure projects 
(Table 2). Levene's test for homogeneity of variance was violated for building and civil infrastructure projects $(\mathrm{p}=0.04<0.05)$, which indicates that population variances were different in each group and the Welch-Satterthwaite test for testing the means should be performed. This test revealed that at the $95 \%$ confidence level, the logarithm of rework costs varied by project type $(\mathrm{p}=0.014<0.05$; IC $95 \% 0.275 \div 2.260)$.

\begin{tabular}{|c|c|c|c|c|c|c|}
\hline $\begin{array}{l}\text { Levene's test for } \\
\text { equality of } \\
\text { variances }\end{array}$ & $\begin{array}{l}\text { t-test for equality } \\
\text { of means }\end{array}$ & & & & $\begin{array}{r}95 \% \mathrm{C} \\
\text { inte } \\
\text { dif }\end{array}$ & $\begin{array}{l}\text { idence } \\
1 \text { of } \\
\text { nce }\end{array}$ \\
\hline Sig. & Df & $\begin{array}{c}\text { Sig. } \\
\text { (2-tailed) }\end{array}$ & $\begin{array}{c}\text { Mean } \\
\text { difference }\end{array}$ & $\begin{array}{l}\text { Standard } \\
\text { error } \\
\text { difference }\end{array}$ & Lower & Upper \\
\hline
\end{tabular}

$4.4957 \quad 0.04057$

Equal variances not assumed*

$2.6077 \quad 30.749 \quad 0.01394 \quad 1.26805$

0.48626

$0.27599 \quad 2.26011$

* Welch-Satterthwaite test

Table 2. t-Test to Compare the Two Samples (Builidng versus Civil infrastructure projects)

Although previous studies (Bresnen et al., 1989; Abdul-Rahman, 1993; Josephson and Hammarlund, 1999; Barber et al., 2000; Love and Li, 2000; Love, 2002) suggest that project type is an attribute rather than a causal factor, and thus will not influence project performance, project types are linked to the concept of complexity and thus influence project performance (Naoum and F.H Mustapha, 1994) as can be seen in this analysis.

Figure 1 shows that building projects incur higher rework costs than civil engineering projects. This suggests that complexity not only involves the kind of works and activities, but also the managerial intricacy of having many stakeholders, tight schedules and generally non-specialized clients.

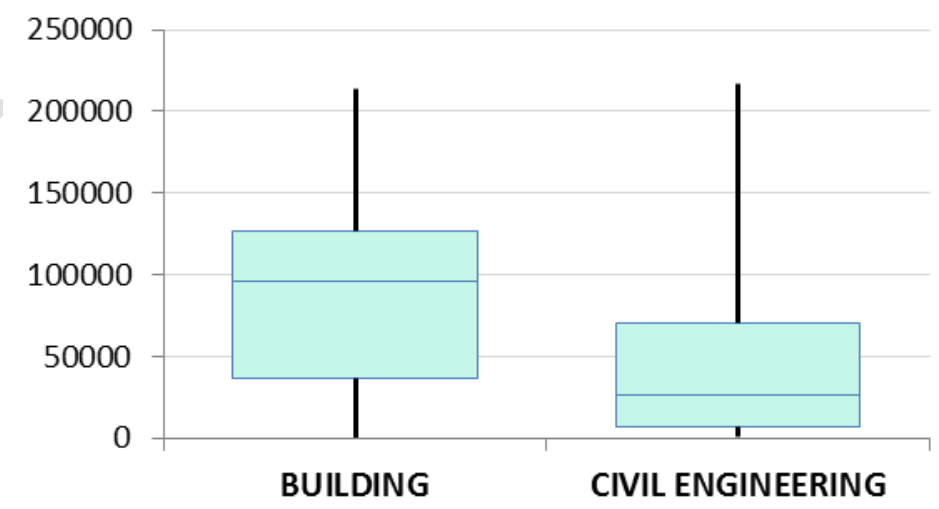

Figure 1. Box plot - project type vs. cost of rework $(€)$ 
In fact, civil engineering projects and building projects are very different in nature, but also in contractual arrangements and participants' skills and experience. In Spain, 2\% of companies account for 55\% of civil engineering turnover, and the 28 largest companies account for $20 \%$ of national activity. In the nineteenth century subcontracting was the collaborative mechanism par excellence (Martin \& Gonzalez, 2011). However, since 2007, Spanish legislation on public procurement has promoted joint ventures for companies that have adequate levels of specialization and efficiency. As a result, a relatively large number of medium-sized enterprises that had previously taken on the role of subcontractors have started to win major contracts through alliances with industrial and financial partners. The technical requirements in building projects are lower, and a large number of companies are qualified enough. The smallest companies (1-9 employees) are responsible for $26.7 \%$ of the business turnover. These small companies carry out $77 \%$ of refurbishment and maintenance projects (Martin \& Gonzalez, 2011).

Regarding project location in relation to headquarters, the significance of the ShapiroWilkinson test for a normal distribution was not less than or equal to 0.05 for any sample ( $\mathrm{p}=0.890$ for local projects, $\mathrm{p}=0.072$ for regional projects, $\mathrm{p}=0.208$ for national projects and $\mathrm{p}=0.985$ for international projects). It can thus be assumed that the logarithm of rework costs in both groups have a normal distribution. An ANOVA was performed to determine whether the logarithm of rework costs varied among project locations in relation to the company headquarters. There was a non-significant difference between groups $(\mathrm{F}(3,36)=2.745, \mathrm{p}=.057$ ) (Table 3 ). Tukey's post hoc test also revealed that there was no statistically significant difference within any group $(p>0.05)$ (Table 4).

\begin{tabular}{lccccc}
\hline & Sum of squres & gl & Mean square & F & Sig. \\
\hline Between groups & 23.390 & 3 & 7.797 & 2.745 & .057 \\
Within groups & 102.256 & 36 & 2.840 & & \\
\hline Total & 125.646 & 39 & & & \\
\hline
\end{tabular}

Table 3. Anova test to compare project locations

\begin{tabular}{|c|c|c|c|c|c|c|}
\hline \multirow[b]{2}{*}{ (I) Region } & \multirow[b]{2}{*}{ (J) Region } & \multirow[b]{2}{*}{ Mean (I-J) } & \multirow{2}{*}{$\begin{array}{l}\text { Standard } \\
\text { error }\end{array}$} & \multirow[b]{2}{*}{ Sig. } & \multicolumn{2}{|c|}{$\begin{array}{l}\text { 95\% Confidence interval of } \\
\text { difference }\end{array}$} \\
\hline & & & & & Lower & Upper \\
\hline \multirow[t]{3}{*}{ Local } & Regional & -1.2795 & 0.7297 & 0.312 & -3.2450 & 0.6858 \\
\hline & National & -1.8792 & 0.7573 & 0.080 & -3.9189 & 0.1603 \\
\hline & International & -2.6564 & 1.1409 & 0.110 & -5.7293 & 0.4165 \\
\hline \multirow[t]{3}{*}{ Regional } & Local & 1.2795 & 0.7297 & 0.312 & -0.6858 & 3.2450 \\
\hline & National & -0.5997 & 0.6293 & 0.777 & -2.2945 & 1.0951 \\
\hline & International & -1.3768 & 1.0603 & 0.570 & -4.2325 & 1.4789 \\
\hline \multirow[t]{3}{*}{ National } & Local & 1.8792 & 0.7573 & 0.080 & -0.1603 & 3.9189 \\
\hline & Regional & 0.5997 & 0.6293 & 0.777 & -1.0951 & 2.2945 \\
\hline & International & -0.7771 & 1.0794 & 0.889 & -3.6844 & 2.1301 \\
\hline \multirow[t]{3}{*}{ International } & Local & 2.6564 & 1.1409 & 0.110 & -0.4165 & 5.7293 \\
\hline & Regional & 1.3768 & 1.0603 & 0.570 & -1.4789 & 4.2325 \\
\hline & National & 0.7771 & 1.0794 & 0.889 & -2.1301 & 3.6844 \\
\hline
\end{tabular}

Table 4. Tukey post hoc test to compare project locations 
However, Figure 2 shows that international projects experiment higher rework costs than local projects.

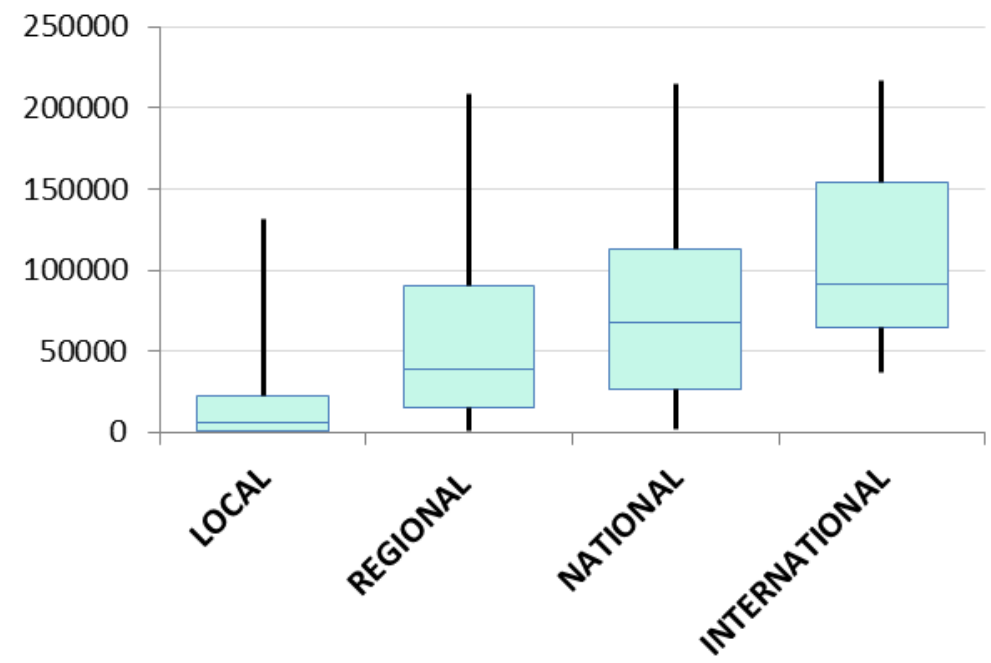

Figure 2. Box plot - Project location in relation to headquarters vs. cost of rework $(€)$

\subsection{MANAGERIAL ASPECTS}

In terms of the type of contract, the significance of the Shapiro-Wilkinson test for a normal distribution was not less than or equal to 0.05 for either sample ( $\mathrm{p}=0.055$ for public projects, $\mathrm{p}=0.918$ for private projects). It can thus be assumed that the logarithm of rework costs in both groups have a normal distribution. A t-test was performed to determine whether the logarithm of rework costs varied between public and private projects (Table 5). Levene's test for homogeneity of variances was violated for public and private contracts $(\mathrm{p}=0.021<0.05)$, which indicates that the population variances were different in each group, and the Welch-Satterthwaite test for the means had to be performed. This test revealed that at the $95 \%$ confidence level, the logarithm of rework costs varied by type of contract ( $\mathrm{p}=0.019<0.05$; IC $95 \%-2.050 \div-0.200$ ).

\begin{tabular}{|c|c|c|c|c|c|c|c|c|c|}
\hline & \multicolumn{2}{|c|}{$\begin{array}{c}\text { Levene's test for } \\
\text { equality of } \\
\text { variances }\end{array}$} & \multicolumn{2}{|c|}{$\begin{array}{l}\text { t-test for equality } \\
\text { of means }\end{array}$} & & & & \multicolumn{2}{|c|}{$\begin{array}{l}95 \% \text { Confidence } \\
\text { interval of } \\
\text { difference }\end{array}$} \\
\hline & $\mathrm{F}$ & Sig. & $\mathrm{t}$ & Df & $\begin{array}{l}\text { Sig. (2- } \\
\text { tailed) }\end{array}$ & $\begin{array}{c}\text { Mean } \\
\text { difference }\end{array}$ & $\begin{array}{l}\text { Standard } \\
\text { error } \\
\text { difference }\end{array}$ & Lower & Upper \\
\hline $\begin{array}{l}\text { Equal variances } \\
\text { assumed }\end{array}$ & 5,7902 & 0,02109 & & & & & & & \\
\hline $\begin{array}{l}\text { Equal variances } \\
\text { not assumed } *\end{array}$ & & & $-2,5196$ & 22,714 & 0,01925 & $-1,12589$ & 0,44685 & $-2,05092$ & $-0,20087$ \\
\hline
\end{tabular}

* Welch-Satterthwaite test

Table 5. t-test to compare the two samples (public versus private contracts) 


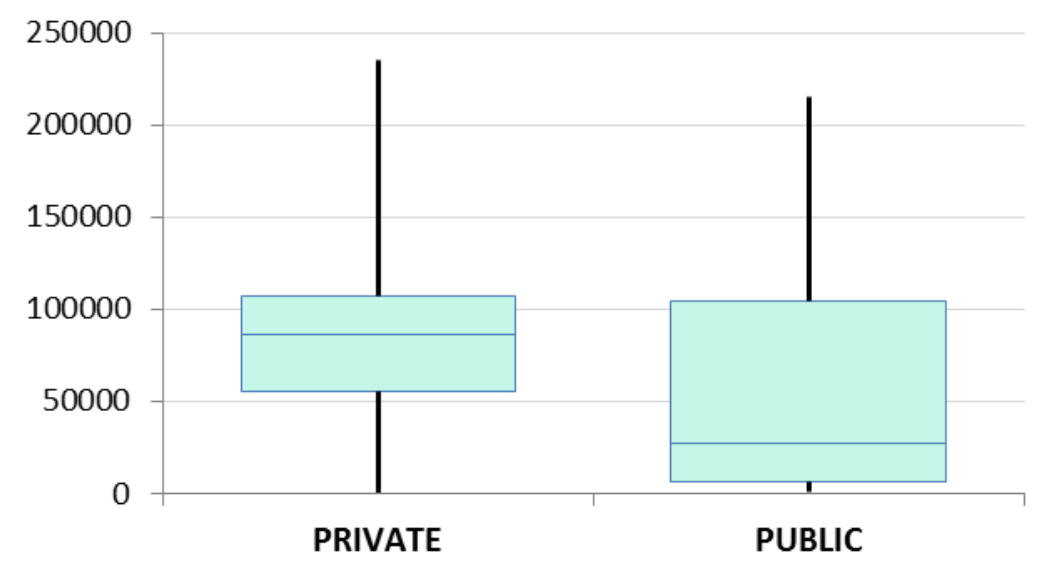

Figure 3. Box plot - Type of contract vs. cost of rework $(€)$

Figure 3 shows that private projects have higher rework costs than public projects. Public projects in Spain are mainly based on competitive tendering, and tend to be procured using the turnkey method, while private projects tend to be procured using a design-bid-build method with high levels of uncertainty (Martin \& Gonzalez, 2011). When there is scope for uncertainty and no contractor involvement during the design stage, the likelihood of claims, disputes and rework costs increases (Love et al., 2012b). The turnkey project delivery strategy may lead to risk-taking by contractors. It forces them to reduce rework costs in order to maximize their margins (Love et al., 2011b). Therefore, when contractual arrangements are strictly fixed, pressure to stick to the OCV might be beneficial to reduce rework costs.

Regarding the type of organization, the significance of the Shapiro-Wilkinson test for a normal distribution was less than or equal to 0.05 for either sample ( $\mathrm{p}=0.046$ for projects including one main contractor, $\mathrm{p}=0.007$ for joint venture projects). It can thus be assumed that the logarithm of rework costs in both groups do not have a normal distribution. Therefore, to determine whether the logarithm of rework costs varied between single and joint venture organizations, a Mann-Whitney U-test for nonparametric variables was performed.

The distributions in the two groups differed significantly (Mann-Whitney $U=79.0, p<$ 0.05 two-tailed). It was thus concluded that the logarithm of rework costs varied significantly between the two samples. Projects managed by joint ventures have higher rework costs than projects managed by a sole contractor (Figure 4), which indicates that complexities derived from poor communication among parties, disputes and managerial aspects in general greatly influence rework costs. 


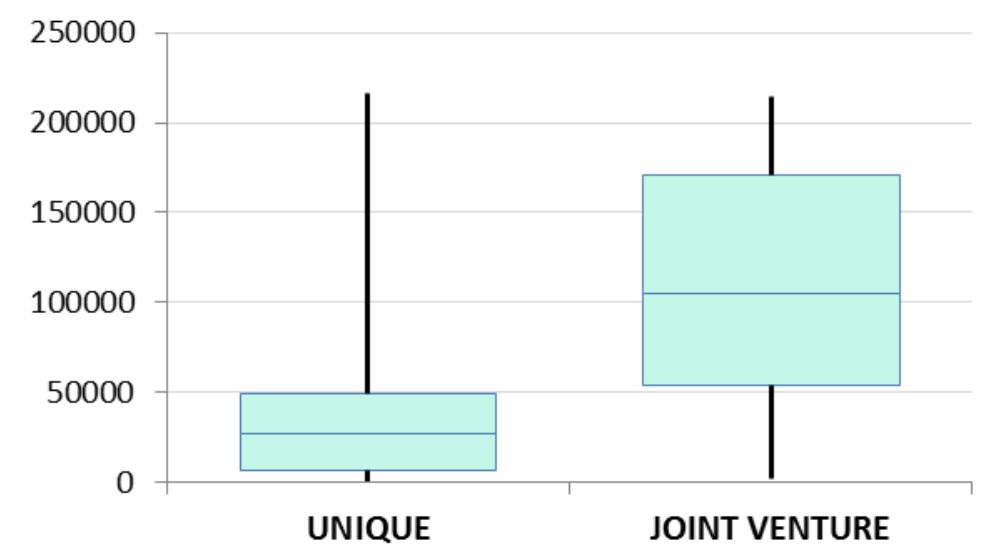

Figure 4. Box plot - Type of organization vs. cost of rework $(€)$

Stakeholders' relationships and differences in goals and quality standards can make communication, organization and day-to-day work difficult (Love et al. 2002). What is considered relevant to one company may not be relevant to another, as a result of sociopolitical, cultural and organizational pressures. This is the case of joint ventures involving many companies that must act as a sole contractor. According to Love et al. (2002, 2009 and 2010), the underlying contributors to rework are mainly related to managerial aspects and strategic decisions taken by top management or key decisionmakers, who may stimulate conditions for the adoption of inappropriate structures, processes, practices and technologies for projects. Consequently, the influence of the type of organization and type of contract on rework costs is justified by different managerial methods used by projects with only one contractor, joint venture projects, and public and private projects. In fact, local practices and contractual agreements have a significant influence on the incidence and cost of rework in any situation and locality (Love et al., 1999).

\section{REWORK REGRESSION ANALYSIS}

When variables are analyzed independently, relations between samples can be determined by a t-test or ANOVA. However, to understand which of the independent variables (project type, project location in relation to headquarters, OCV, OCD, type of contract, and type of organization) are related to the dependent variable (rework costs), and to explore the forms of these relationships, stepwise multiple regression analysis was performed. To that aim, categorical variables (project type, type of contract, type of organization and project location in relation to the headquarters) were converted using a binary coding of $1 \mathrm{~s}$ and 0 s, so that they could be used in the regression analysis. For a given variable, the option assigned the value 1 is arbitrary, because rework costs will be the same, regardless of the coding procedure used.

Regression coefficients represent the mean change in the response variable for one unit of change in the predictor variable, while other predictors in the model are held constant. The statistical control that regression provides is important, because it isolates the role of one variable from all of the others in the model. Table 6 reproduces the 
regression output and includes the unstandardized regression coefficients (B), the standard errors of the regression coefficients (Std. Error), the standardized regression coefficients $(\beta)$, the t-test and the observed significance levels ( $p$-value) for the appropriate predictors of rework costs.

\begin{tabular}{llccccc}
\hline Model 1 & \multicolumn{1}{c}{ Variable } & Coefficient B & $\begin{array}{c}\text { Std, } \\
\text { Error }\end{array}$ & $\boldsymbol{\beta}$ & T & p-value \\
\hline & Constant & -2.502 & 2.049 & & -1.221 & 0.230 \\
& Ln(OCV) & 0.757 & 0.133 & 0.628 & 5.681 & 0.000 \\
& Project location & 0.647 & 0.226 & 0.316 & 2.859 & 0.007 \\
\hline
\end{tabular}

Table 6. Project characteristic predictors of rework costs

The low p-value $(<0.05)$ of OCV and project location in relation to the headquarters indicates that these variables are likely to be a meaningful addition to the model, because changes in the predictor's value are related to changes in the response variable. The regression equation $(\mathrm{R}$-squared $=0.561, \mathrm{p}<0.01)$ is expressed as:

$\operatorname{Ln}($ Rework costs $)=-2.502+0.628 * \operatorname{Ln}(\mathrm{OCV})+0.316 *$ Project Location

The value of $0.561 \mathrm{R}$-squared means that $56.1 \%$ of the rework cost variation is explained by this equation. To validate the model, the homogeneity of variances was verified in an analysis of residuals. The plot of residuals in which the residuals behave randomly suggests that the model fits the data well. The normality of the response was verified by the normal probability plot of residuals. Finally, the scatter plot of residuals versus predictors determines that there is no relation between independent variables $(\mathrm{Ln}(\mathrm{OCV}))$ and responses (random plot).

When all the variables were combined to determine their relations to rework costs, only project location in relation to headquarters and OCV were found to significantly contribute to the regression. Project type, type of organization and OCV/OCD ratio were correlated when they were considered independently. However, they were highly dependent on the OCV. The average OCV for civil engineering projects was lower than the average OCV for building projects. Similarly, the average OCV for projects managed by one organization was lower than the average OCV for projects managed by joint ventures. Therefore, the OCV variable indirectly explains the effect of project type, type of organization and the OCV/OCD ratio which represents the concept of complexity. However, although it is independently correlated, the effect of contract type on the regression model is hidden (i.e. implicit) by the increase in the variance of the other factors. Accordingly, the OCV represents the magnitude of a project and involves other factors such as project type and type of organization. Besides, project location in relation to headquarters includes managerial and cultural aspects that are strongly related to the rework costs. In fact, local, regional, national and international projects involve different types of organizations with different goals and objectives, due to their organization's culture. What is considered relevant to one company may not be relevant to another, as a result of the task they do, as well as socio-political, cultural and organizational pressures. Therefore, the influence of managerial problems and coordination complexities that companies experience when they operate in non-local areas might lead to an increase in rework costs. 
Regression analysis is clearly one of the most important tools available to researchers (Armstrong, 2012). However, tools shape theory as well as how a researcher goes about analyzing data (Woodside, 2013). Although several researchers in construction have sought to pinpoint a single 'root cause' of rework and others have attempted to provide a context to explain the chain of events that lead to its the occurrence, there have been very limited studies that have identified ways in which rework can be actively reduced (Love et al., 2016).

This study analyses the project influential variables by using correlation and regression analysis and found that some factors are included in others. Consequently, the regression model cannot be extrapolated to other samples without an in-depth study of the interrelation of all variables. Moreover, correlation is not causation, so this study is the starting point to use other techniques to delve into rework causation in building projects.

Finally, the identification of rework influential variables can enable quantitative risk assessments to be undertaken prior to the start of construction, and actions for rework reduction can be planned. Prediction and the timely discovery of errors will minimize the extent of the impacts (Palaneeswaran et al., 2006). These results can also be included in tools to reduce rework for proactive construction rework management (Zhang et al., 2012) and tools based on augmented reality with Building Information Modeling (BIM) (Park et al., 2012; Forcada et al., 2014b) among others.

\section{CONCLUSIONS}

Construction cost overrun due to rework is a common problem in the construction field. Identifying the cost-influencing factors is the first step toward addressing such problem. If construction companies can effectively control these key factors and formulate prevention strategies, it is possible not only to avoid cost overrun, but also to increase the overall profits for the project.

The research presented in this paper set out to determine the factors that contribute to rework costs, including project characteristics (project type, project location, OCV, OCD, ACV and ACD) and managerial aspects (type of contract, type of organization and project location), using data from 788 Spanish incidents that occurred in 40 construction projects.

The study revealed that the special features of the Spanish construction sector are influential factors of rework costs. Spanish contractors do not allocate rework to the total cost increase of the project, because rework costs generally have to be absorbed as specified in the contractual arrangement. While the cost of rework was found to be $2.75 \%$ of the OCV and was due to errors and defects assumed by the contractor, the mean cost growth represented $11 \%$ of the OCV and mainly included extensions to the project scope requested by the client. According to the result, during the project, contactors should have clear understanding of the scope of the contract so as to significantly reduce cost overruns. 
This study determines that the original project conditions are crucial factors in the prediction of rework costs. Interestingly, the rework prediction model showed that only the OCV and the project location in relation to the company's headquarters contribute to the regression model (R-squared=0.561). The Project type, the Type of organization, the Type of contract and the OCD which represents the magnitude and complexity of a project, were included in the OCV parameter. Accordingly, the OCV is explained by the kind of works and activities carried out (Project type) and the implication of different organizations with different goals (Type of organization). In addition, complexities when operating in non-local areas and procurement methods derived from the type of project were also factors that were found to influence project performance, and thus rework costs.

The prediction of rework costs based on the OCV and the project location in relation to the headquarters could enable strategies to be put in place prior to the start of construction, to minimize uncertainties and reduce the impact on project cost and schedule, and thus improve productivity and performance. Although the findings of this research are revealing, it is clear that future research is required to further investigate the rework situation in greater depth.

Further research is being considered to expand the database and using other modelling approaches. In addition, studies for mapping the rework impacts on various performance and productivity aspects are also planned.

In summary, this research contributes to a better understanding of factors contributing to rework and their impacts on project performance such as cost and time overrun. The rework regression model can be used as a decision-support system to undertake quantitative risk assessments and to plan actions for rework reduction prior to the start of construction. Prediction and the timely discovery of errors will reduce rework occurrences and enhance project performance levels in the construction industry.

\section{REFERENCES}

Abdul-Rahman, H. (1993). "The management and cost of quality for civil engineering projects", Ph.D. thesis, Univ. of Manchester Institute of Science and Technology, UMIST, Manchester, U.K.

Armstrong, J.S. (2012). Illusions in Regression Analysis. International Journal of Forecasting, 28(4) 689-694.

Ashford, J. L. (1992). "The management of quality in construction", E \& F Spon, London.

Aiyetan, A.O. (2013). "Causes of rework on building construction projects in Nigeria", Journal of Construction Project Management and Innovation 12(3), 1-15.

Battikha, M. G. (2008). "Reasoning mechanism for construction nonconformance rootcause analysis", J. Constr. Eng. Manage, 134(4): 280-288.

Barber, P; Graves, G. A., Hall, M., Shearth D \& Tomkins C. (2000). "The cost of quality failures in major civil engineering projects", International Journal of Quality and Reliability Management, 17 (4/5): 479-492.

Bertelsen, S (2003). "Complexity: construction in a new perspective." 11th Annual 
conference in the international group for lean construction, Blacksburg, VA.

Bresnen, M.J., Haslam, C.O., Beardsworth, A.D., Bryman, A.E. \& Hell, T.E. (1988). "Performance on site and the building client", Occasional Paper 42, Chartered Institute of Building, Ascot, UK.

Burati, J. L., Farrington, J. J., Ledbetter, W. B. (1992). "Causes of quality deviations in design and construction”, J. Constr. Eng. Manage., 118(1): 34-49.

Construction Industry Institute (CII) (2001). "The field rework index: early warning for filed rework and cost growth", Austin, TX: The University of Texas at Austin. Report No. RS 153-1, May.

Davis, K., Ledbetter, W. B. \& Burati, J. L. (1989). "Measuring design and construction quality costs", Journal of Constr. Eng. and Man.. 115(3): 389-400.

De la Cruz, P., del Caño, A. \& de la Cruz, E. (2008). "New paradigms for public procurement of construction projects in the United Kingdom - potential applicability in Spain", Canadian Journal of Civil Engineering. 25:276-286.

Forcada, N., Rusiñol, G., Macarulla, M. \& Love, P.E.D. (2014a). "Rework in highway projects", Journal of Civil Engineering and Management. 20(4): 445-465.

Forcada, N., Beca, J.M., Macarulla, M., Gangolells, M. \& Casals, M. (2014b). “A BIM model to visualize quality risks in construction projects", 9th European Conference on Product and Process Modelling (ECPPM), Viena, Austria.

Forster, N. (1994), "The analysis of company documentation", in Cassell, C. and Symon, G. (Eds), Qualitative Methods in Organizational Research, Sage Publications, London.

Fayek, A. R., Dissanayake, M. \& Campero, O. (2003). "Measuring and classifying construction field rework: A pilot study", Research Rep. (May), Construction Owners Association of Alberta COAA. The University of Alberta, Edmonton, Al., Canada.

Georgiou, J., Love, P. E. D. \& Smith, J. (1999). “A comparison of defects in houses constructed by owners and registered builders in the Australian State of Victoria", Structural Survey, 17(3): 160-169.

Gidado, K (1996). "Project complexity: The focal point of construction production planning." Construction Management and Economics, 14, 213-25.

Hwang, B., Thomas, S., Hans, C. \& Caldas, C. (2009). "Measuring the impact of rework on construction cost performance", Journal of Construction Engineering and Management, 135 (3): 187-198.

Hwang, B-G., Zhao, X. \& Goh, K.J. (2014). "Investigating the client-related rework in building projects: The case of Singapore", Int. Jou. of Proj. Man., 32(4), 698-708.

Ilozor, B. D., Okoroh, M. I., Egbu, C. E. \& Archicentre. (2004). "Understanding residential house defects in Australia from the State of Victoria", Building and Environment, 39(3): 327-337.

Josephson P.E. \& Hammarlund, Y. (1999). "The causes and costs of defects in construction. A study of seven building projects", Autom. in Constr. 8(6).

Josephson, P.E., Larsson, B.\& Li, H. (2002). "Illustrative benchmarking rework and rework costs in Swedish construction industry", J. Manage. Eng. 18(2): 76-83.

Jaafari, A., Chan, M.A., Cassab, R. (1994)." Quality management in the Australian construction industry", Wakefield, R.R. and Carmichael, D.G. (Eds), Construction and Management, Recent Advances, Balkema, Rotterdam, 89-112. 
Jahren, C. T. \& Asha, A. M. (1990). "Predictors of cost-overrun rates", J. Constr. Eng. Manage., 116(3): 548-552.

Jingmond, M. \& Ågren, R. (2015). "Unravelling causes of defects in construction", Construction Innovation, 15(2): 198-218.

Kakitahi, J.M., Alinaitwe, H. M., Landin, A. \& Rodrigues, M.J.A. (2014). "Comparison of construction related rework in Uganda and Mozambique", Journal of Construction, Project Management and Innovation, 4(1), 770-781.

Li, Y. \& Taylor, T. (2014). "Modeling the Impact of Design Rework on Transportation Infrastructure Construction Project Performance." J. Constr. Eng. Manage., 10.1061/(ASCE)CO.1943-7862.0000878, 04014044

Love, P.E.D. \& Wyatt, A.D. (1997). "Communication and Rework: Case Studies of Construction Projects", CSIRO, DBCE DOC 97/38 (B), Australia.

Love, P.E.D., Mandal, P. \& Li, H. (1999). "Determining the causal structure of rework", Construction Management and Economics. 17(4): 505-15.

Love, P. E. D., Li, H. \& Irani, Z. (2000). "Construction rework: The multiplier effect in practice", 5th Int. Conf. on ISO 9000 \& TQM School of Business, HK Baptist Univ. \& Productivity \& Quality Research Centre, National Univ. of Singapore, Singapore, 435-439.

Love, P. E. D. \& Li, H. (2000). "Quantifying the causes and costs of rework in construction", Constr. Manage. Econom. 18(4): 479-490

Love, P. E. D. (2002). "Influence of project type and procurement method on rework costs in building construction projects", J. Constr. Eng. Manage., 128(1): 18-29.

Love, P.E.D, Holt, G.D., Shen, L.Y1, Li, H., Irani, Z. (2002). "Using systems dynamics to better understand change and rework in construction project management systems", International Journal of Project Management, 20(6): 425-436.

Love, P.E.D. \& Smith, J. ( 2003). "Bench-marking, bench-action and bench-learning: rework mitigation in projects", J. Manage. Eng. 19(4): 147-159.

Love, P. E. D. \& Edwards, D. (2004). "Forensic project management: The underlying causes of rework in construction projects", Civ. Eng. Environ. Syst., 12(3): 207228.

Love, P.E.D., Smith, J. \& Walker, D. (2009). "Congruence or divergence? A path model of rework in building and civil engineering projects", Journal of Performance of Constructed Facilities, 23 (6): 480-488.

Love, P., Edwards, D., Watson, H. \& Davis, P. (2010). "Rework in Civil Infrastructure Projects: Determination of Cost Predictors", J. Constr. Eng. Manage. 136(3): 275282.

Love, P. \& Edwards, D. (2013). "Curbing rework in offshore projects: systemic classification of risks with dialogue and narratives", Structure and Infrastructure Engineering. 9(11): 1118-1135.

Love, P.E.D. \& Sing, C-P. (2013). "Determining the probability distribution of rework costs in construction and engineering projects", Structure and Infrastructure Engineering. 9(11): 1136-1148.

Love, P.E.D., Teo, P., Carey, B., Sing, C-P. \& Ackermann, F. (2015). "The symbiotic nature of safety and quality in construction: Incidents and rework nonconformances", Safety Science, 79: 55-62.

Love, P.E.D., Edward, D. J. \& Smith, J. (2016). "Rework Causation: Emergent Theoretical Insights and Implications for Research", J. Constr. Eng. Manage., 10.1061/(ASCE)CO.1943-7862.0001114, 04016010 
Martin, R. \& Gonzalez, J. (2010). "Strategic analysis of the construction industry in Spain", Cuadernos de Gestión, 11(1): 141-161.

Mills, A., Love, P., Williams, P. (2009). "Defect Costs in Residential Construction", J. Constr. Eng. Manage. 135(1): 12-16.

Naoum, S., Mustapha, F.H. )1994). "Influences of the client, designer and procurement methods on project performance", Proceedings of CIB W-92 Procurement Systems Symposium, 4-7 December, East Meets West, Department of Surveying, The University of Hong Kong, Hong Kong, 221-8.

National Economic Development Office (NEDO) (1987). "Achieving Quality on Building Sites", Millbank, London, UK, 18-19.

Oyewobi L. O, Oke, A.A, Ganiyu B.O., Shittu A.A., Isa R.S. \& Nwokobia L. (2011). "The effect of project types on the occurrence of rework in expanding economy", Journal of Civil Engineering and Construction Technology 2(6): 119-124

Oke A.E., Ugoje, O.F. (2013). "Assessment of rework cost of selected building projects in Nigeria”, Int. Jour. of Qual. \& Rel. Man.. 30(7): 799-810.

Odeck, J. (2004). "Cost overruns in road construction: What are their sizes and determinants?", Transport Policy, 11(1): 43-53.

Park, C.S., Lee, D.Y., Kwon O.S. \& Wang, X. (2012). "A framework for proactive construction defect management using BIM, augmented reality and ontology-based data collection template", Automation in Construction. 30: 61-71.

Palaneeswaran, E., Ramanathan M. \& Tam C-M. (2007). "Rework in Projects: Learning from Errors", Surveying and Built Environment, 18(2): 47-58.

Palaneeswaran, E., Love, P. E. D. , Kumaraswamy, M. M. and Ng, Thomas S. T.(2008) "Mapping rework causes and effects using artificial neural networks", Building Research \& Information, 36(5): 450 - 465.

Sommer, B. \& Sommer, R. (1992). "A Practical Guide to Behavioral Research: Tools and Techniques", Oxford University Press, New York, NY.

Sommerville, J. \& McCosh, J. (2006). "Defects in new homes: an analysis of data on 1696 new UK houses", Structural Survey, 24(1): 6-21.

Taggart, M, Koskeal, L. \& O'Rourke, J. (2014). "The role of the supply chain in the elimination and reduction of construction rework and defects: an action research approach", Construction Management and Economics, 32(7/8): 829-842.

Wanberg, J., Harper, C., Hallowell, M.R. \& Rajendran, S. (2013). "Relationship between Construction Safety and Quality Performance", Journal of Construction Engineering and Management, 139(10): 04013003.

Watt, D. S. (1999). "Building pathology: principles \& practice”, UK.

Walker, D. H. T. (1994). "An investigation into the factors that determine building construction time performance", $\mathrm{PhD}$ thesis, Department of Building and Construction Economics, Faculty of Environmental Design and Construction, Royal Melbourne Institute of Technology, Melbourne, Australia.

Wood, H. L. \& Gidado, K. (2008). "An overview of complexity theory and its application to the construction industry." Dainty, A (Ed) Procs 24th Annual ARCOM Conference, 1-3 September 2008, Cardiff, UK, Association of Researchers in Construction Management, 677-686.

Woodside , A. G. (2013). Moving beyond multiple regression analysis to algorithms: Calling for adoption of a paradigm shift from symmetric to asymmetric thinking in data analysis and crafting theory Journal of Business Research, 66 (2013) 463-472. 
Ye, G., Jin, Z., Xia, B., \& Skitmore, M. (2014). "Analyzing causes for reworks in construction projects in China", Journal of Management Engineering.

Yung, P. \& Yip, B. (2010). "Construction quality in China during transition: A review of literature and empirical examination”, Int. J. Project Manage. 28(1): 79-91.

Zhang, D., Haas, C., Goodrum, P., Caldas, H. \& Granger, R. (2012). "Construction Small-Projects Rework Reduction for Capital Facilities", Journal of Construction Engineering and Management, 138(12), 1377-1385. 